\title{
Environmental problems and environmental governance in the context of dynamic economic growth - the case of China
}

\begin{abstract}
The fast growing anchor countries have become key players in mitigating global environmental change. China is a very particular anchor country. The size, scope and quality of the environmental degradation associated with its dramatic economic growth is much larger than that of all the other anchor countries. Despite being regarded as an all-embracing emerging superpower, China is a very heterogeneous country regarding its economic, social and environmental structure. Regional differences require an effective response. However, China's environmental governance system is characterized by a number of weaknesses, which impede the implementation of targets and objectives set by policies and laws. The most significant weakness refers to the insufficient institutional framework for horizontal and vertical policy coordination. Good environmental governance requires measures that address these deficiencies. Furthermore, the diffusion of public information on the costs of environmental degradation and the rule of law have to be promoted as complementary measures.
\end{abstract}

\section{Introduction}

Global environmental change - exemplified by global warming and its widespread consequences - is one of the biggest challenges human society is facing in the $21^{\text {st }}$ century. The challenge consists in limiting the scope of change by addressing the causes of massive environmental degradation, while at the same time adapting to its impacts. Combating environmental degradation has become more difficult than in the $20^{\text {th }}$ century: So far, the OECD world had been the largest consumer of environmental goods and services. When multilateral environmental agreements were negotiated, e.g. the treaty on fisheries in the North Sea, the cost of reducing the consumption of environmental resources had to be distributed fairly among relatively equal partners. Today, with the economic rise of China, India, Brazil and other emerging economies from the developing world, the share of these countries in consuming natural resources and polluting ecosystems has grown as well, and global treaties on environmental objectives and related burden-sharing agreements are complicated by issues of equity and fairness, both regarding historical responsibilities as well as the opportunities for future growth ("right to development").

Differences among industrialized countries relate mainly to the absolute size of their economies and to variations in development paths and consumption patterns/lifestyle, while differences between industrialized countries and anchor countries are exemplified by enormous gaps in per capita incomes and per capita consumption rates of the environment, which illustrate backlogs in economic and social development.

Until the beginning of the $21^{\text {st }}$ century, degradation of ecosystems was caused fundamentally by economic growth in industrialized countries and the related absolute increase in environmental consumption. The expected further economic growth of anchor countries will exacerbate environmental degradation not only on local level, but on a global scale. Due to its sheer size, China plays an extraordinary role regarding its environmental impact among the anchor countries and has caught up with the industrialized countries. The ecological footprint as an environmental indicator illustrates this role. Ecological footprints indicate what an economy needs from nature in form of inputs, e.g., resources, and outputs, e.g., greenhouse gas (GHG) emissions, waste, and show whether a nation is living within its ecological limits or consumes more than its own biocapacity (i.e., the total area of biologically productive land). Today, according to the Worldwatch Institute $(2006,17)$, the US, the EU, Japan, China and India are consuming $75 \%$ of 
the global biocapacities. Regarding absolute figures, only the US and the European consumption have a larger impact on the environment than the Chinese consumption. The Chinese ecological footprint amounts to $18 \%$ of global biocapacity. However, comparing per capita footprints the picture looks different. The average Chinese footprint is 1.6 ha of the global biological productive space and therefore well under the world's average of 2.3 global ha whereas the European, the Japanese, and the US footprints with $4.7,4.8$ and 9.7 ha are definitely above average (Worldwatch Institute 2006).

Among the anchor countries, China is the most populous and its economy grows at an enormous pace. These characteristics, together with the incredible speed of far-reaching economic and social changes the country has absorbed and produced during the last decade, make China a quite unique case among anchor countries.

Many industrialized countries observe with concern the environmental situation in China and intensely demand on China to take action. It is hoped on the one hand, that by China's response the global situation can be alleviated and on the other hand, that China's behaviour will positively affect other developing countries with regard to their environmental performance. Especially in the international negotiation of environmental agreements China is still allying with developing countries and often represents this group. However, it seems so far

Fig. 1: Environmental problems in China

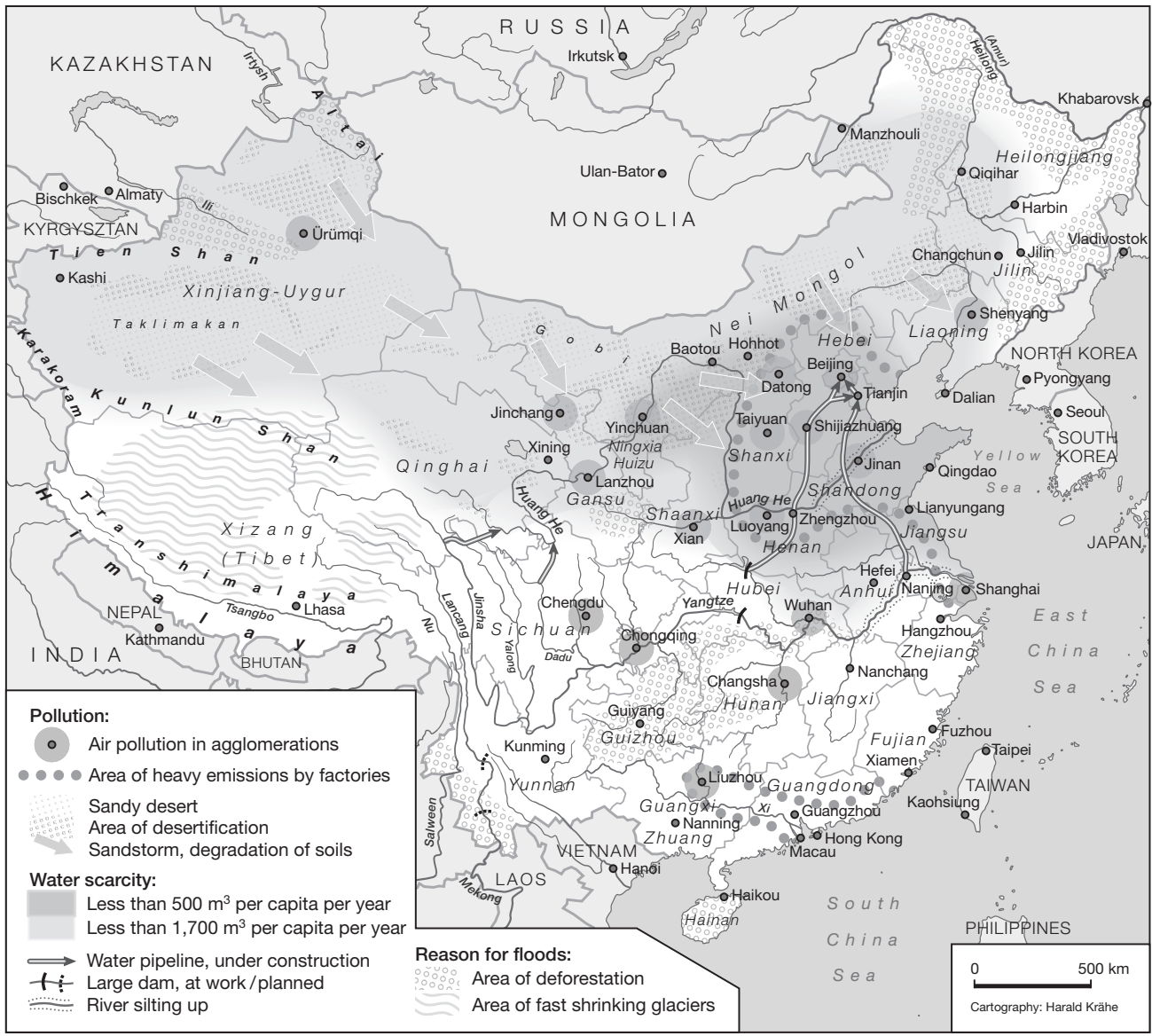

Source: Le Monde Diplomatique (2006): Atlas der Globalisierung. Paris/Berlin, 201; New York Times 2007 
that the influence of the international community on China with regard to environmental policy has been considerable. Due to these reasons, we choose China as a case to investigate the scope of environmental problems and the shape of environmental policies in the context of dynamic economic growth.

Environmental degradation in China can be traced back to both market and policyfailures: During the last three decades, far-reaching economic reforms triggered a rapid process of economic growth. China externalised all environmental costs because there were no economic incentives for increasing efficiency in the use of energy, water, and other resources. At the same time, administrative measures for environmental control were not adequate: Policy coordination between central, provincial and local levels was and continues to be weak, and there are no effective sanctions. The four key elements of good environmental governance, which are critical to achieving environmental effectiveness are: 1) consensus and sciencebased objectives reflected in policies, laws and regulations; 2) appropriate institutional framework for policy development and implementation (including allocation of responsibilities); 3 ) institutions and instruments for policy integration and coherence (reflecting environmental, economic and social dimensions); 4) provision of information, public participation and access to an impartial judiciary.

\section{Spatial and environmental impact of China's economic growth}

The environmental situation in China is severe. A study by the World Bank and SEPA (The State Environmental Protection Administration) (2007) on the cost of pollution estimates that the economic burden of premature mortality and morbidity associated with air pollution is between 1.16 and $3.8 \%$ of GDP. China's rapid economic development plays a decisive role for the critical environmental situation.

The relationship between economic growth and environment is controversial. On the one hand, some argue that economic growth requires higher inputs of energy and material, which increase for example air pollution and global warming, and generates more waste. This will lead to an overuse of the biocapacity of the Earth and result in environmental degradation, reducing hu- man welfare and eventually putting economic growth itself at risk. On the other hand, others argue that environmental protection is only possible by economic growth because higher incomes change consumption patterns towards less material and energy intensive products. Another group of researchers suggest the environmental Kuznets curves as an adequate model to describe the inverted- $U$ relationship between economic growth and environmental degradation (PANAYOTOU 2003, $1 \mathrm{f}$.). That implies that in the early stages of economic growth environmental degradation increases but later at some level of development the trend reverses and the environmental situation improves. The theory of the environmental Kuznets curve is also controversial, since it cannot be applied to all environmental indicators (e.g. energy use still increases in later stages of economic development) and the testing results have not been robust (PERMAN/ STERN 2003). Looking at China and its environmental indicators, it is clear that China is at a stage where economic development harms the environment to such an extent that it is questionable whether China will be able to compensate the damages when it is economically more advanced.

To understand the environmental impact of China's dynamic development and its environmental impacts one has to consider the country's natural spatial dimension which has three important characteristics: 1) China is the third largest country on earth; 2) a large diversity of landscapes, ranging from plateaus and mountainous regions to deserts and lowlands; and 3) marked seasonal opposites, including regions with a monsoon climate (45\% of mainland China's area and nearly $90 \%$ of its arable land) as well as areas with temperate summers and cold winters (North and Northeast), the Himalayas, and the deserts in the West and Northwest. North China has the best soils, but long winters and unreliable rainfall patterns reduce agricultural yields. Southern China has the strongest precipitation and the longest natural growth period, but acid and leached soils.

\section{Economic development}

Over the last 30 years, China's economic system has gone through deep reforms, which replaced central planning by market-based mechanisms and integrated production and consumption into the world economy. Between 1992 and 1995, the annual GDP growth rate was on average $12.2 \%$, since then the average (1996-2002) 
dropped to $7.2 \%$ and in 2004 it increased again to $9.5 \%$. These growth rates are supported by a rapid structural change from agriculture to industry and services (LAI 2003,10; World Bank 2005). Since 1978 a division of labour assigning certain functions to specific regions on the macro and meso level is emphasised by central government. This model has led to the establishment of numerous economic zones or regions on different spatial scales. Economic and social inequality has increased between regions in China (TAUBMANN 2007, 40):

- the traditional gap between East and West: the Eastern coastal provinces are profiting from economic growth, while the isolated rural West is lagging behind;

- the gap between urban and rural areas: affluent urban areas are surrounded by much poorer rural areas; this is true for both the East as the West;

- the gap between North and South along the coastline: economic integration between the Southern coast and Hong Kong, Macau and Taiwan has left the North behind, whose economic structure is still characterised by heavy industry and whose neighbouring countries Russia and North Korea - do not offer possibilities for dynamic economic change.

At the same time, China's participation in the world markets and foreign trade increased significantly, which means that the local and global environmental impact of China's growing economy is ultimately linked with consumption patterns in those countries that import Chinese goods. The country has become a leading exporter of manufactured goods, ranging from clothes to wooden furniture to electronic goods. However, China has also become a major importer of raw materials such as minerals, timber and oil. Such production patterns are usually linked with an increasing burden on the environment.

Domestic consumption with negative environmental impacts has also grown due to higher incomes, improved living standards and a substantial reduction of poverty. Private vehicle ownership has increased from 20,000 to approximately 7.6 million in 2002 in just 25 years, yet only eight of every 1,000 Chinese own a car (SCHIPPER/NG 2004, 5/41). However, in per capita terms the country still belongs to the lower middle-income group and more than 100 million Chinese fall below international poverty lines (RAVALLION/CHEN 2004).

The degradation of ecosystems is exacerbated by the uneven distribution of the Chinese population. In the 1980s, about $94 \%$ lived in Eastern China, on $43 \%$ of the national territory. Already in the $19^{\text {th }}$ century and in the 1930 s, ecological crises were the manifest consequence of this situation (TAUBMANN 2007, 27). Urbanisation has been promoted since the foundation of the People's Republic of China in 1949, as part of its industrialisation strategy. This strengthened middle-sized towns and cities throughout the country. Rural-urban migration was controlled, and the growth of large cities restricted. But after 1978, economic and regional policies aiming at modernisation and integration into the world economy reinforced the old dominant position of the coastline cities, e.g. Shanghai, and facilitated uncontrolled urban growth (TAUBMANN 2007, $30 \mathrm{ff}$.).

Economic growth and shifts of production and consumption patterns in China have not only led to severe environmental problems but also to an enormous increase of energy demand. China's economy is still based on an energyintensive industry. China is the second largest energy consumer in the world and energy is mostly provided by coal. Coal releases almost twice as much $\mathrm{CO}_{2}$ per unit of energy as natural gas and causes air pollution through sulphur dioxide $\left(\mathrm{SO}_{2}\right)$, nitrogen oxides $\left(\mathrm{NO}_{\mathrm{x}}\right)$ and other particulates (CHANDLER et al. 2002, 13). China is the second largest greenhouse gas emitter in the world and it is expected that China will overtake the US in 2008 (IEA 2006).

Fig. 2: Regional disparities in China

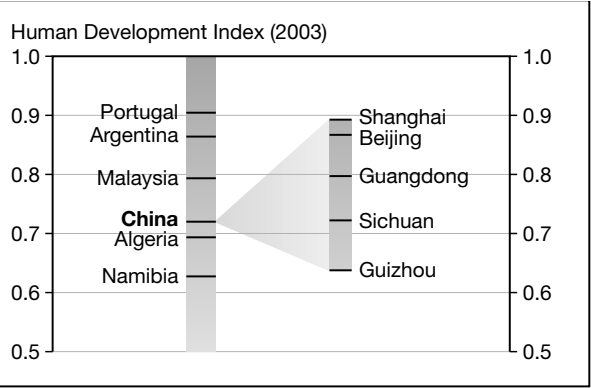

Source: UNDP, 2005, 59 
Estimations indicate that China's total primary energy consumption will more than double between 2000 and 2020, with continuous heavy reliance on coal (WORLD BANK 2006, 50). China's increasing urbanisation will also contribute to the increase of energy demand, because the rural population (more than $60 \%$ of total population) consumes limited energy at the moment (BANG/HegGelung/VEVATNE 2005, 13). Furthermore, China uses its energy sources inefficiently. The inefficient ratio is reasoned in China's specific energy structure and an outdated technological infrastructure. Energy prices are too low and do not set incentives for conservation (HATCH 2003, 47). However, per capita energy use in China is low compared to international standards (Fig. 4).

Rapid economic growth, massive use of resources and regional inequalities are accompanied by serious environmental pollution and resource degradation. The largest impacts on ecosystems and humans are due to the contamination of fresh water, air pollution, acid rain, desertification, the impact of climate change, and the loss of forests and biodiversity. Moreover, pollution and resource scarcity have become major sources of social unrest and massive migration throughout the country (ECONOMY 2004, 25). Environmental damages vary among provinces because each province has a different balance of environmental problems. However, the areas with highest population density are mainly concerned with air and water pollution (World Bank/SEPA 2007, xii).

Contamination of fresh water with urban, industrial and agricultural pollutants diminishes the quality of drinking water and causes health problems. Between 2001 and 2005, about $54 \%$ of the seven main Chinese rivers con-

Fig. 3: $\mathrm{CO}_{2}$ emission trends

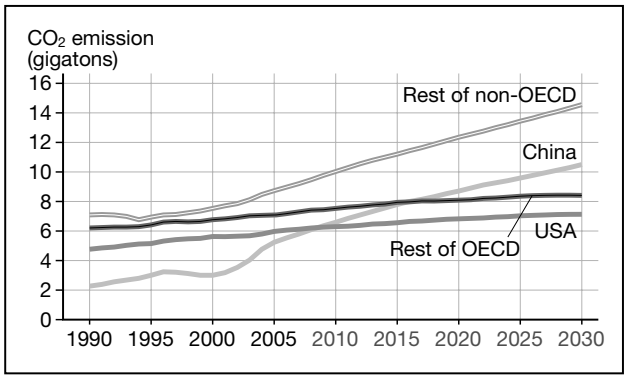

Source: IEA 2006 tained water deemed unsafe for human consumption - a $12 \%$ increase since the 1990s. The most polluted rivers are in the northeast. Since surface water is polluted, pressure has been put on the use of groundwater for agricultural and industrial purposes. Pollution leads to water scarcity in the North of China. Especially the poor suffer from water pollution. About 115 million people in rural China rely on surface water as drinking water. In general, it is observed that water quality has improved in the water-rich south and decreased in the water scarce north (World Bank/SEPA, 2007, xiii, 6).

Air pollution is caused by particulates and gases that arise through energy production, manufacturing, and transport. Air quality in many Chinese cities falls well below international standards. World development indicators show that 16 of the world's 20 top polluted cities are Chinese (SEI/UNDP 2002, 26). Based on the data of the Chinese Air Pollution Index (API), there are currently at least 170 million urban residents experiencing air with a quality below what is considered acceptable by the Chinese ambient air quality standard. Air pollution causes various respiratory and heart diseases (SEI/UNDP 2002, 31).

Air pollution occurs in two forms: atmospheric and indoor. Atmospheric pollution results mainly from coal-burning and transport. The largescale, inefficient utilisation of poor quality coal leads to large emission of pollutants. Industrial boilers and furnaces consume almost half of China's coal and are the largest single point sources of urban air pollution (World Bank 1997, 12). Indoor air pollution is a severe prob-

Fig. 4: Per-capita primary energy demand in selected countries, 2005

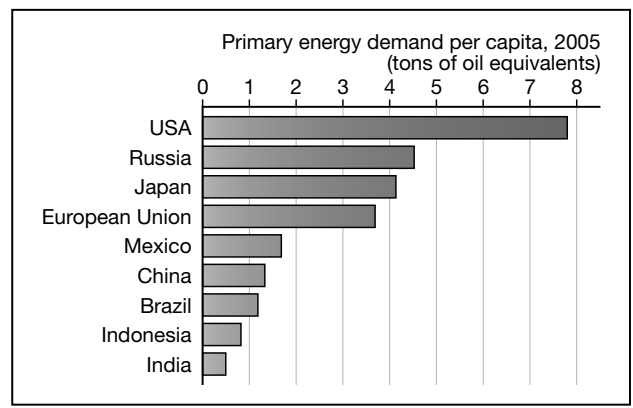

Source: IEA 2007, 266 
lem in China. Small-scale heating and cooking cause thick, sticky smoke saturated with soot and a mix of other pollutants (SEI/UNDP 2002, 27). A large portion of the population, especially in rural areas, is regularly exposed to pollutant levels well above national ambient standards. Most households still burn solid fuels like raw coal and wood for cooking and heating. Indoor combustion produces particulates, $\mathrm{SO}_{\mathrm{x}}$ and $\mathrm{NO}_{\mathrm{x}}$, carbon monoxide, and other pollutants (World Bank 1997, 12).

Since 1980, the number of vehicles is growing annually at a rate of $20 \%$ in many urban areas. It is estimated that the number of cars in China will rise from 20 million upwards to 50 million by 2010 . With the exception of greenhouse gas emissions, the main pollutants in transport exhausts are $\mathrm{NO}_{\mathrm{x}}$, but given the poor level of maintenance, a wide range of toxic substances including lead, carbon monoxide, and hydrocarbons are very much a concern (SEI/UNDP 2002, 27).

Acid rain, emerging from $\mathrm{SO}_{2}$ and soot caused by coal combustion, is both a problem within China and a transboundary environmental problem, affecting China's neighbouring countries. About $30 \%$ of China's total land area has been affected by the long-range transport of acid raincausing pollutants. The same has already caused serious damage outside of China, e.g. in Japan. Acid rain is associated with many types of damage, from effects on human health to destruction of boreal and subtropical evergreen forests. According to one estimate, by 2002 acid rain caused almost US\$ 13.3 billion in damage in China annually (ECONOMY 2004, 72). Impacts include damage to agricultural crops and forests, reduction on food production, destruction of lake ecosystems, and damage of buildings (SEI/UNDP 2002, 29). Direct effects occur mainly near the sources of emissions. Some of the most sensitive ecosystems in southern China may already have been damaged by acid precipitation. A survey of forest growth in Sichuan Basin and Guizhou Province has documented that forest damage (indicated by rates of tree and foliage growth) is higher in areas with highly acidic rain (World Bank 1997, 28 f). However, acid rain is only one source of soil pollution among others such as industrial and municipal solid wastes, wastewater used for irrigation, remains of plastic film, and excessive use of chemical fertilizer and pesticides (SEI/UNDP 2002, 22).
Desertification, i.e. degradation and loss of arable land, is a massive problem in China. It is mainly caused by unsustainable agricultural practices and the uncontrolled growth of urban areas. Agricultural production has intensified in order to maintain the growing population. Intensive production methods also rely on a higher energy use which again is associated with increased emissions and pollution (CCICED 2004, $25 \mathrm{ff}$.). Erosion is a major problem in the transition area between temperate North China and the Mongolian savannah, where a large loess plateau is found. More than half of this area is seriously degraded by erosion. In the Northwest and West, desertification is a serious problem due to overgrazing, extensive growth of agriculture, and deforestation (fuelwood). Nearly $20 \%$ of arable land are salinized, especially irrigated land in North China (TAUBMANN 2007, 19).

Agricultural yields are affected also by unsustainable production systems: the content of organic nutrients in the soils is decreasing. In large industrial and urban areas, soils and water are heavily polluted. On the average, several 100,000 ha arable land are annually lost in the fertile eastern lowlands due to the growth of industrial areas, and urbanisation. Between 1952 and 2003, arable land per capita was thus halved, from 0.19 ha to 0.10 ha. While yields have been increased constantly during the same time period, a new trend can be observed since the 1980s: with improving living standards, direct consumption of grains decreases, while more and more grains are used for producing meat, fish, milk and eggs. Loss of arable land and changing consumption patterns, together with a growing population, will lead to an increasing dependency on food and fodder imports (TAUBMANN 2007, 20).

China strongly contributes to global warming and climate change but it also suffers from it. Climate change exacerbates existing environmental problems. China has several climatic zones and a varied physical environment (i.e., long coastlines, spans of arid and semi-arid lands), which make China very vulnerable to the negative impacts of climate change in specific regions. Researchers expect that compared to other regions, China will be subject to the largest total damages and market damages related to global warming due to the relatively big size of the economy and the relatively high share of land in temperate zones, which are more vulnerable to climate change than tropical 
areas. Since 1980, the annual average temperature in China has increased by 0.6-0.8 degree centigrade. Estimations suggest that in 2100, China will experience US\$271 billions of market damages (e.g. in agriculture, forests, fisheries) and US $\$ 652$ billions of non-market damages (e.g. in terms of biodiversity loss, air pollution, migration) if temperature increases by 2.7 centigrade (1990 level). This will be equivalent to $1.5 \%$ of the future GDP. The world total market damages and non-market damages are estimated to be US\$ 880 and US\$ 3,276 billions respectively (Li/NISHIOKA 1999, 12).

There is some evidence for small increases in precipitation over arid and temperate regions of China, which may have a positive impact on agricultural production combined with higher temperatures. In tropical areas the picture looks different. Here, annual precipitation, atmospheric humidity and the number of foggy days have all decreased. Combined with increases in annual temperature, this has lead to a drier climate and increased soil and vegetation moisture stress (HuLME/SHEARD 1999, 2).

Another worrying trend is that the glaciers in the High Asia region of Northwest China are shrinking as a result of global warming. In the last 40 years glaciers have shrunk more than $6,606 \mathrm{~km}^{2}$ in the whole Tibetan plateau with the greatest retreat occurring since the mid1980 s. The retreat of the glaciers has significant impacts on local, regional and global environmental services such as water supply, glacial debris flow hazards, flooding, lakes' drying and rising, unstable river and streamflows, and constitutes a threat for animals and plants and their habitats (SHEN 2004, 3). The 1990s retreat was the most rapid of the 20th century, and caused an increase of more than $5.5 \%$ in the runoff of glacial melt water in Northwest China (UNEP 2004).

The sea level along China's coast is rising at an enormous speed over the past five decades and recently with an annual increase of 2.6 millimetres. Consequently, coastal regions are disappearing. It is predicted that the sea level will rise by 30 to 70 centimetres by 2100 . Besides, ocean temperatures off the Chinese coast have risen in the last 100 years, especially since the 1960s. China's long coastline harbours $70 \%$ of the country's large cities, more than half of the domestic population and nearly $60 \%$ of the national economy (People's Daily Online
2002). According to Chinese studies, a one meter rise in sea level, combined with storm surges and tide, could flood an area the size of Portugal (including the cities of Shanghai and Guangzhou), displacing 67 million people at 1997 population levels (World Bank 1997, 15).

Extreme weather events have always constituted a risk for agricultural production in China, especially floods and droughts. Climate change can influence the frequency and the intensity of extreme weather events but also the direction in which they take effect. China and its population are increasingly haunted by such as droughts, flooding, tropical cyclones, sand storms, and heat waves, which are aligned with extreme damages. In the 1990s, between 20 and 30 million ha were affected by floods, droughts, blights, typhoons and hailstorms, reducing their yields on average by at least $30 \%$ in comparison to a normal year (TAUBMANN 2007, 25). Usually, droughts occur in the north of China and floods in the south the so-called northern drought and southern flood pattern - but not necessarily. For example, 2003 was marked by severe droughts and high temperatures in the south and an extremely wet season with almost record setting flooding in the north. These led to economic losses totalling US\$ 24 billion in 2003 (Xinhua 2004). Droughts also affect drinking water sources. In 2001, more than half of the 4,000 lakes in the Qinghai province were reported to be disappearing and more than 120 drinking water sources ran dry due to droughts (Environmental Defense et al. 2006).

Chinese researchers predict that increased greenhouse gas concentrations in the atmosphere will lower rice, wheat and cotton production because of higher temperatures, increased soil evaporation, and more frequent and severe storms (World Bank 1997, 15). In 2006, the drought in the north, northeast and south-western regions affected 16.3 million ha of farm land and threatened supplies of drinking water to more than 14 million people and 11.55 million livestock. Floods affected about 4.5 million people in central, eastern and southern regions with direct agricultural economic losses totalling more than US\$ 330 million (Planet Ark 2006).

Forests and land are under pressure due to population growth and the expansion of cities, and climate change will exacerbate this pressure. 
With one hectare per capita, forest areas have reached a very low level. With this number, the country ranks significantly below the world average of 0.6 hectare per capita. However, despite its enormous economic growth, China has been able to stabilize the deforestation rate and forest areas have increased between 2000 and 2005 by $2.2 \%$ (FAO 2007).

Biodiversity in China is not only seriously threatened by deforestation and acid rain but also by other human activities such as overexploitation of animal and plant resources, pollution, and the introduction of invasive species. Of the 640 species listed by the Convention on International Trade in Endangered Species (CITES), $25 \%$ are found in China, and 15 to $20 \%$ of Chinese plant and animal species are endangered (ECONOMY 2004, 66). Emissions increase the pressure on species. For example, lichens are sensitive to atmospheric $\mathrm{SO}_{2}$ and HF (hydrofluoric acid), and have disappeared from the suburbs of many cities and forests near sources of such pollution. The loss of biodiversity is not only a problem because ecosystems are destroyed and certain functions cannot be maintained. China is also undermining its biological capacity to adapt to climate change.

\section{Environmental governance in China}

Over the past two decades, the environment has been given an increasing attention in China, but economic goals have always been priority. The Chinese government has enacted many environmental laws, which are implemented through a decentralised structure since 1998. However, the severe environmental situation in China and the fall-short of environmental targets prove that the institutional framework is neither effective nor efficient (OECD 2005, 498). For example, China has not been able to meet 10 of its 13 critical targets formulated in the $10^{\text {th }}$ five-year-plan for air and water pollution (World Bank/SEPA 2007, 1). In sum the evolution of the environmental governance system has not been able to keep up with economic growth and its negative impacts on natural resources and the environment. Therefore, effective implementation is a challenge.

\section{Policies, laws and regulations}

Environmental problems were included in China's political agenda when China stopped to consider environmental problems as an attribute of capitalist development, after the 1972 UN
Conference in Stockholm (NORDQvisT 2005, 17). China's first Environmental Protection Law was adopted in 1979. It was amended in 1989 but it is still the fundamental environmental law being in force. It provides the general framework for allocating administrative responsibilities. Furthermore, it identifies target areas for environmental protection and natural resources conservation work, specifies measures for the control of environmental pollution and other public hazards, and outlines legal liabilities for violations. The law introduces some basic principles (i.e. principle of harmonic development, principle of preventive action, polluter-paysprinciple) governing the prevention of pollution and environmental protection and imposes criminal responsibility for serious environmental pollution (DASGUPTA et al. 2001, 490).

Today, China has nine laws on environmental protection and 15 laws on the protection of natural resources, formulated or revised over 50 administrative regulations, and promulgated over 800 national environmental protection standards (State Council of the People's Republic of China 2006). Important examples are the Law on the Prevention and Control of Air Pollution of 1995 and the Environmental Impact Assessment Law of 2003. The latter requires every project with a potential negative effect on the environment to be reviewed (OECD 2005, 503). Economic instruments have also been adopted to complement the regulatory system, for example a system for the compensation of ecological damage (OECD 2005, 504).

However, in many cases the law is only inadequately applied. Environmental laws are generally regarded to be too broad and to provide local officials with little guidance on implementation. Responsibilities are not clarified, executive provisions are not formulated, and existing regulations and instruments are sometimes not consistent. The success of the market instruments has also been very limited because they often lack the necessary administrative, market and enforcement mechanisms (ECONOMY 2004, 101/92).

\section{Institutional framework for policy development and implementation}

The most important environmental institution is the State Environmental Protection Administration (SEPA). It has similar responsibilities to a ministry for the environment but has not reached the same rank as a ministry in terms of 
authority. However, SEPA is responsible for formulating national environmental rules, methods and standards (HoNGJUN/FERRIS 1998, 6). Its opponent is the National Development and Reform Commission (NDRC), which formulates China development plans and which is the most powerful ministerial institution.

The Chinese response to urgent environmental problems is a top down approach. Activities are based on policies set at the central level and implemented by administrative measures and campaigns in form of bans to stop undesired activities and/or investment programmes to promote positive developments. For example, between 1995 and 2000, more than 84,000 heavily polluting plants were shut down. However, many activities are not effective. Especially campaigns, a very popular instrument, face the problem that they often fail to achieve the desired results because they are characterized by high up-front investments but little follow-up, by the lack of inclusion of local officials and business and by not providing and using efficient instruments and technologies that change behaviour (ECONOMY 2004, 121).

On the local level, all provinces and municipalities have established Environmental Protection Bureaus (EPB). There are more than 3,000 EPB with 167,000 officials engaging in environmental administration, monitoring, scientific research, publicity, and education. Besides, there are 3,854 environmental supervision and environmental law enforcement organs with more than 50,000 staff members (State Council of the People's Republic of China 2006). They have concrete obligations to implement the targets provided by the central government, which has the overall responsibility to develop regulations and monitor their enforcement. Substantive implementation, however, is mainly carried out at the provincial levels. The bureaus have a number of affiliated units such as, for example, inspection or research units. Each EPB reports to the upper level EPB and the head of their administration unit (e.g. mayor's office) since the bureaus are part of the provincial administrations and their funding depends on them. SEPA has only little influence on these bureaus. Only recently, SEPA received the right to participate in the selection of the heads of the local EPB (OECD 2005, $500 \mathrm{f}$.).

Decentralisation has made implementation of China's environmental laws more complicated.
China is a centralised state with a strong hierarchy but local governments have gained considerable economic and financial power through the economic reforms (SEI/UNDP 2002, 68). Provincial, city, township and village governments, and local environmental protection bureaus assume greater responsibility for environmental protection and resource management. However, China's size and complexity makes it difficult for the central government to oversee the actions on the local level. Often, local officials are overwhelmed with their task because they lack training and access related to new laws and regulations and the capacity to interpret laws (SEI/UNDP 2002, 78).

The incentive structure of local officers for good environmental performance is weak. Promotion schemes are mainly based on economic performance and not on environmental-friendly activities and usually they work on shortterm contracts, which do not provide the opportunity to adopt long-term perspectives. However, the Chinese government has identified such weak points and put forward some changes. Local EPB were strengthened and the governmental administration is now responsible for environmental protection instead of leaving the responsibility only with the EPB (OECD 2005, 510).

Since the 1990s, the central government has started to counterbalance the regional disparities by reformulating its regional policy. This was necessary because the decentralisation of economic decision-making power had exacerbated competition for resources and investment, and made cooperation more difficult. This, in turn, weakened policy coordination for natural resource management and environmental protection as well as the implementation of existing policies and the compliance with laws (TAubMANn 2007, 39 ff.).

SEPA mainly applies soft civil and administrative sanctions (e.g., fines and warnings) to enforce environmental law but they seem to be ineffective (SchwarTz 2004, 31). For example, fees for polluting enterprises are set so low that many firms prefer to pay the fines every year instead of modernising their factories with costly pollution-control equipment (ECONOMY 1998, 20). SEPA and EPB do not have sufficient power, for example, they are not allowed to shut down production lines or whole enterprises to penalize non-compliance. 
$\mathrm{Bi}$ - and multilateral cooperation plays a key role for strengthening environmental institutions and developing their capacities. China is the largest recipient of environmental aid from the World Bank and the Global Environmental Facility (GEF), and it receives large amounts from other aid agencies, especially the Asian Development Bank (ADB) and the United Nations Development Programme (UNDP). Of China's environmental budget $80 \%$ comes from abroad (ECONOMY 2004, 189). This opens the door for a huge impact from a donor perspective. However, China's relationship with international donors and its status as recipient have changed. The World Bank for example has sharply reduced funding because China does not qualify anymore for International Development Assistance (IDA) funds and because NDRC strongly controls which projects receive World Bank funding (ECONOMY 2004, 190).

\section{Policy integration and coherence}

Today, China experiences a significant lack of horizontal integration, i.e., ineffectual coordination between environmental and sectoral decision-making, and a lack of vertical integration between different levels of policy-making and implementation (e.g. local, regional and national). Before environmental and sustainable development considerations entered the political agenda, China was quite successful in dealing with single sector measures due to its strong centrally planned vertical power structure with many ministries and agencies aiming at economic growth. However, this structure is overstrained when trying to approach cross-sectoral issues such as environmental problems. From 1992 onwards, in view of the dramatic environmental situation, China's approach regarding environmental governance changed. Since then, the principle of sustainable development has been incorporated into China's planning processes, the participation of the civil society and the creation of nongovernmental organizations (NGO) have been supported, and marketbased pricing for energy sources (i.e., coal) has been strived for (ECONOMY 2004, 100).

China abolished production-oriented sectoral ministries or reformed their structure by complementing them with sustainable development or environmental units. After the government reform in 1998, institutions with crosscutting responsibilities in the area of environment and sustainable development were developed or strengthened. SEPA was promoted (SchwarTZ 2004, 29). However, SEPA also competes with other government bodies for limited resources and influence, as for example the Ministry of Construction which deals with urban environmental issues (water supply, wastewater treatment) and the Ministry of Water Resources, which controls soil erosion, watershed management and groundwater quality. SEPA has no permanent seat in the State Council but is subject to the State Council's approval of its proposals. Furthermore, an adequate mechanism to coordinate activities and safeguard the realisation of environmental objectives is lacking. As a consequence, SEPA has narrowed its activities to a scope that does not cause any interference or requires coordination with other bodies (OECD 2005, 508).

Vertical integration is impeded by conflicts between national and local decision-makers, especially between SEPA and the local governments. EPB and SEPA are perceived as "policemen" impeding economic growth by enterprises and local governments. Local EPB are subordinated to upper level EPB and finally SEPA, but funding and supervisory functions are provided by local governments. These have often different views on environmental and development issues than SEPA, in particular, if the local government partly or fully owns a polluting enterprise or managers of the enterprise hold positions in the party committee, in the local government or the Congress. In this case the local government may block EPB activities (OECD 2005, 509).

In order to improve policy integration and coherence, SEPA strives to raise awareness on the impacts of environmental degradation on economic growth. In 2005, SEPA and the $\mathrm{Na}$ tional Bureau of Statistics of China (NBS) launched a pilot programme for a green GDP accounting system in ten provinces and municipalities, which measures the real domestic wealth, i.e. conventional GDP less the costs of environmental degradation and natural resource loss. In China the green GDP concept is regarded as an instrument to stop local governments from continuing the single-minded pursuit of growth objectives ignoring environmental costs. The concept is still quite undeveloped and only applied in very few countries (e.g., Norway and Mexico). In 2006, SEPA and NBS published "China Green National Accounting Study Report 2004". According to 
this report, environmental pollution cost China about US\$ 64 billion in 2004, accounting for $3.05 \%$ of the GDP. The environmental costs of water pollution, air pollution and solid wastes and pollution accidents accounted for $55.9 \%, 42.9 \%$ and $1.2 \%$ of the total costs respectively. These already high numbers still have to be considered as underestimating environmental costs because only ten of 20 categories of environmental pollution were included in the calculations (ZHENG/CHEN 2006, $4 \mathrm{f}$.).

Climate policy is an example for policy integration and coherence which is relevant for environmental policy because of the many interfaces between these two policy fields, e.g. regarding the linkages between measures for clean air and measures for reducing $\mathrm{CO}_{2}$ emissions - increasing energy efficiency and energy saving has a positive effect in both areas because coal combustion for electricity generation causes both air pollution and $\mathrm{CO}_{2}$ emissions. Climate change policymaking is assigned to NDRC because climate change is framed not as an environmental problem but as an international cross-cutting issue that involves energy policy, national economic development, and foreign affairs, as well as environmental concerns (LEE 2005, 149). Thus, climate change figures much higher on the political agenda than environmental protection. Whether cross-sectoral policy coordination will work in the case of climate change, and whether it will work better than in the case of environmental protection, remains to be seen. One hypothesis, which would have to be tested by further research, could be that in the case of reducing greenhouse gas emissions, efforts for policy integration and coherence could be successful because they are inseparable from energy policy and economic development, and cannot be regarded as blocking economic growth because of external considerations. Another hypothesis could be that the strong impacts of climate change on Chinese natural conditions and chances of future growth may help to create awareness on the necessity to improve environmental protection and thus further environmental policy coherence. YU (2004) argues that in the case of climate change, policy coordination is facilitated by the need to build on a consensus based on thorough scientific knowledge of the problem and not mainly on interest-based negotiations; and by a strong influence of the norms created by the international climate regime.

\section{Information, public participation}

and the rule of law

Information: Media are substantial sources of information, they have the potential to monitor the government's and the industry's activities and raise awareness about environmental issues among the civil society. China has a good media coverage. Chinese media have become increasingly independent of direct government control and pressures and are exposed to market pressure and consumers' demand instead. Media has taken an increasing interest in the environmental situation and environmental reports are now an important part of media coverage.

Media (as well as environmental NGOs) have established a cooperative arrangement with the government. Media and NGOs that operate responsibly and within a scope acceptable to or even demanded by the Chinese government are granted more freedom and increased political participation (SEI/UNDP 2002, 71). The government makes use of the power of media and the increase in awareness in order to support environmental initiatives of the government or to improve the implementation of environmental laws. For example, the government has set up an award system to set incentives for the report of environmental violations (SEI/UNDP 2002, 48).

About five years ago, public awareness of environmental issues was intentionally low in all parts of China. Today, however, it appears that it is the political will of Chinese leaders to increase academic knowledge and raise awareness on environmental issues (NORDQVIST 2005, 21). Research institutes and universities play an important role in providing new and impartial information on the state of the environment. In China, these institutions have a very close relationship with government although they are not governmental institutions. Usually, they are non-profit organisations that provide service to the government. In the past, research on environmental issues was mainly concerned with natural science and technology issues and conducted in think tanks (e.g., Chinese Academy of Sciences) and universities, while applied and policy-relevant research was carried out by governmental institutions. Today, these institutions have gained a stronger role and evolved to independent or semi-independent research institutions and think tanks. Since 1998, research institutions are allowed to make profits and sell their expertise. Increas- 
ing academic exchange and the involvement of Chinese experts in environmental development cooperation helped institutions to become increasingly independent from government support and control (SEI/UNDP 2002, 88).

In order to make government policies more transparent to Chinese people and the rest of the world, China publishes reports on the environment. Many environmental laws and regulations comprise provisions to issue bulletins on the environment. In line with these requirements, SEPA and EPB regularly circulate reports on the state of the environment. The media also publishes reports on the environmental situation, e.g., on water quality of river basins. More than 2000 environmentally-related websites exist where organisations and individuals can inform the public. However, they are controlled by the government (OECD 2005, 518). Since 1990, the Information Office of the State Council has published so-called White Papers. They broach the policy issues of human rights, labour and social security, gender, defence, and also environmental problems (CHAN 2006, 24). In June 2006, the Information Office issued a 45-page white paper titled "Environmental Protection in China (19962005)", which gives an overview on China's efforts to protect the environment in the last ten years and confirms the important role of the environment for economic development. Furthermore, through China's participation in the negotiations of multilateral environmental agreements the country was called upon, e.g., to report on climate data and to take a stand in negotiations regarding scientific and policy issues. China was forced to publicly communicate the results and its position. However, much of the available information is still confidential and distributed only among high-level government officials (OECD 2005, 523).

Public participation: Possibilities for participation in policymaking outside the formal channels are limited, given that China is a socialist country. However, political reforms that introduced market-orientated instruments in the 1990s also increased chances for participation. Economic actors gained freedom of decision and influence. Local governments gained power, and also public participation in China has significantly increased. Since the 1980s, village-level elections have become increasingly prevalent and elections of National People's Congress (NPC) deputies and township governors take place in various provinces (YE 2003, 10). Being aware of the fragility of their positions, further democratic reforms were neglected by the Chinese communist party. A more dramatic change is the development of the NPC from a place where decisions were only communicated to a forum for open discussion. Moreover, citizens can directly make complaints to the government by sending unsigned letters to the government (e.g., mayor offices, local People's Congress, EPB) or using established hotlines for residents to report environmental problems (OECD 2005, 521).

Although the environmental NGO-community in China is considered as the most advanced manifestation of Chinese civil society, compared with western NGO they have a different meaning (SCHWARTZ 2004). Chinese NGO are divided into GONGO (government organised NGO), which receive governmental financial and human support, and grassroots NGO, which are more independent and do not rely on governmental financial support (Lu 2005, 2). The term government organised NGO sounds paradoxical. However, GONGO are clearly established within the existing political structure and give operational support to ministries and departments. While SEPA has used its limited resources to carve out a niche for itself in advancing environmental policy, environmental GONGO have been able to amplify its impact. Often, GONGO members are former government officials trained within the state system. Through the close relationship between government and GONGO the scope for actions of the latter (e.g., selection of research areas, critical statements) is limited. In return, they have fewer funding concerns, undertake high quality research and have a greater policy impact (SCHWARTZ 2004, 42 f).

The development of NGO in China has been difficult due to administrative regulations that govern the operation and activities of NGO. About 2,000 registered environmental NGO exist in China, but it is estimated that there are about 100,000 environmental groups operating in China which call themselves non-profit enterprises or university student environmental groups to avoid the tedious NGO registration process (SIARNACKI 2006). There are a few positive examples of Chinese NGO's influence on the policy process. In 2006, Chinese NGO, coupled with local activists, were able to convince the government to temporarily stop work on a dam on the Nujiang River that would dis- 
place 50,000 people while the project is reviewed (Asahi Shimbun, 5/10/06 cited in SIARNACKI 2006). Foreign and international NGO are not subject to the regulations that were established for domestic NGO.

The rule of law: Participation depends on the implementation of the rule of the law. Rule of law implies that official regulations are known by the public and can be carried out through a transparent mechanism according to foreseeable procedures (UNDP 2005, 113). In China the rule of law was not always self-evident. Since 1979, the Chinese government has tried to change the tradition of arbitrary decisionmaking by gradually separating the lawmaking process from the political agenda in order to strengthen the rule of law. Before these reforms, decisions were taken by influential or respected individuals rather than through laws or regulations. Networks of informal relationships played an important role (OECD 2005, 516).

Today, China has a comprehensive set of rules and laws, especially in the environmental sector, but it is weakly enforced and the laws themselves do not provide effective sanction mechanisms. Many decisions are still taken by individuals under short-term and profit-orientated considerations while ignoring the law. Especially environmental problems are often a consequence of actions that aim at profits but are contradictory to the legal set-up. The power of individuals creates opportunities for and even supports corrupt behaviour. Just recently, SEPA's director said that a government investigation into pollution control approvals for construction projects worth more than US $\$ 12.5$ million had found violations in almost $40 \%$ of the cases (Lague 2006). Individual decisions regarding enforcement are usually taken case-by-case and depend on the social connections of the decision-maker. Therefore, in some cases, enterprises that had broken the law were not fined in order to maintain harmonious relationships. Traditionally, in China conflicts are solved through informal negotiations, i.e. mediation and conciliation, and not through lawsuits (OECD 2005, 514).

However, the reforms of the last 20 years have led to an increasing number of environmental legal cases, including commercial litigation cases, lawsuits against the government, and civil lawsuits. Class action suits against local officials have become accepted means of attaining redress against corrupt local officials (ECONOMY 1998, 16). Nevertheless, corruption, judicial ignorance of the law, and pressures on judges distort the system. EBP often avoid the efforts and cost to collect the data needed for evidence in a lawsuit (OECD 2005, 516).

\section{Conclusions}

During the last decade, rapid economic growth has turned China into a global player on the economic arena. In the globalized contemporaneous world, this new economic power is accompanied by new political responsibilities with regard to global cooperation. In the field of global environmental change, China's new responsibilities are particularly visible: economic growth exacerbated traditional environmental problems, such as water scarcity and soil erosion, and it created new problems such as air pollution and dramatically rising greenhouse gas emissions. The economic and social cost of environmental overconsumption is becoming more and more visible in China. At the same time, due to the geographic and economic size of China, domestic consumption of environmental resources has an immediate bearing on global ecosystems and sink capacities, even though per capita consumption remains low, compared with averages in industrialized countries.

From this background, China needs to improve the effectiveness and efficiency of its environmental governance system, in order to secure the ecological basis for future socio-economic development, and to be able to meaningfully participate in global negotiations on environmental protection. At present, China's environmental governance system is characterized by a number of weaknesses, which impede the implementation of targets and objectives set by policies and laws. The most significant weakness refers to the insufficient institutional framework for horizontal and vertical policy coordination. This insufficiency seriously limits the actual implementation of environmental governance although its basic elements - environmental laws as well as a sectoral agency with ministerial status and protection bureaus on provincial and local level - are there. Horizontal coordination, i.e. coordination between environmental and sectoral decision-making, has been weakened by the abolition of a coor- 
dinating agency. Despite its ministerial status, SEPA alone is not strong enough to impose an environmental agenda on other sectoral ministries. NDRC, the main coordinating body for policy planning, does not place environmental issues high enough in order to integrate it into its strategic work.

An exceptional new case is climate change, where a system of coordinated policymaking is emerging under NDRC. In July 2007, China published its national climate strategy, which documents all policies and measures for the reduction of greenhouse gas emissions. The $11^{\text {th }}$ Five-Year-Plan includes targets and measures for increasing energy efficiency, improving energy conservation, and promoting renewable energies. Climate protection is linked to the energy sector, which is central to economic growth, and therefore the incentive for policy coordination may be stronger than in the case of air and water pollution, soil erosion etc. where the benefits of internalizing environmental costs into production or consumption are not immediately felt. This case may offer a new path of coordinated policymaking.

Vertical coordination is weakened by ineffective decentralization and economic reforms, which have given more autonomy to provincial and local authorities but did not ensure integration. Until recently, regional policies were conceived at central level and propagated a functional division of labour among regions. This exacerbated tensions between regions and central government and made vertical policy coordination and implementation more difficult: regional authorities effectively strive for economic development, and disregard environmental policy aims and laws in this process. Economic aims are so dominant that the autonomy and strength of local environmental protection bureaus is seriously hampered. SEPA has no direct influence on these bureaus. Measures are required that ensure the compatibility of economic and environmental aims and strengthen the enforcement capabilities of environmental advocators.

As the control function of central executive authority is weakening, two complementary options are likely to become unavoidable in the future, if the implementation of policies and laws shall be promoted: One is the diffusion of public information on the costs of environmental degradation, through the media and the action of NGO and GONGO. Another one is the promotion of the rule of law, e.g. by giving prosecutors the responsibility to control whether the executive authorities on the various administrative levels are fulfilling their legal obligations with regard to the protection of public goods. Both mechanisms could operate on a decentralised and autonomous basis, and thus be adapted to the vast diversity of local economic, social and natural conditions typical for China.

\section{Literature}

Bang, G./ G. Heggelung / J. Vevatne (2005): Shifting strategies in the global climate negotiations: A strategic cooperation project. Alternatives to the Kyoto Protocol. Lysaker. (Fridtjof Nansen Institute, FNI Report 6/2005).

CCICED (China Council for International Cooperation on Environment and Development)(2004): An environmental impact assessment of China's WTO accession: An analysis of six sectors. Winnipeg. (International Institute for Sustainable Development).

Chan, G. (2006): China's compliance in global affairs. Trade, arms control, environmental protection, human rights. Singapore. (Series on Contemporary China 3).

Chandler, W. / Schaeffer, R./ Zhou, D./ Shukla, P.R./ Tudela, F./ Davidson, O./ Alpan-Atamer, S. (2002): Climate change mitigation in developing countries: Brazil, China, India, Mexico, South Africa, and Turkey. Arlington. (Pew Center on Global Climate Change).

Dasgupta, S./ Laplante, B./ Mamingi, N./ Wang, H. (2001): Inspections, pollutions prices, and environmental performance: evidence from China. In: Ecological Economics, (36)3, 487-498.

ECONOMY, E. C. (1998): China confronts the challenge of globalization. Implications for domestic cohesion and international cooperation. New York.

ECONOMY, E. C. (2004): The river runs black: The environmental challenge to China's future. New York.

Environmental Defensel Natural Resources Defense Council/ Sierra Club/ Union of Concerned Scientists/ U.S. Public Interest Research Group/ World Resources Institute/ World Wildlife Fund (2006): Global warming: early warming signs. Internet: http://www.climatehotmap.org/index.html, 9.8. 2006.

Haтch, M. T. (2003): Chinese politics, energy policy, and the international climate change negotiations. In: Harris, P. G. (Ed.): Global warming and East Asia. The domestic and international politics of climate change. London, 43-65.

Honguun, Z./ FerRIs, R. J. (1998): Shaping an environmental protection for the new century. China's environmental legal framework. In: Sinosphere, (1)1, 6-9, 13.

Hulme, M./ Sheard, N. (1999): Climate change scenarios for China. Norwich. (Climatic Research Unit; Internet: http:/www.cru.uea.ac.uk/ mikeh/research/wwf. china.pdf, 15.6. 2005). 
IEA (International Energy Agency)(2006): World energy outlook 2006. Paris.

IEA (International Energy Agency)(2007): World energy outlook 2007. Paris.

Lague, D. (2006): Corruption is linked to pollution in China. In: International Herald Tribune 21.8.2006; Internet: http://www.iht.com/articles/2006/08/21/news/ smog.php, 12.12. 2007.

LAI, P. (2003): China's economic growth: New trends and implications. In: China \& World Economy, (11)1, 9-15; Internet: http://www.iwep.org.cn/pdf/2003/ wec_2003_1-2_laipingyao.pdf, 10.5. 2005

LEE, H.-C. (2005): China and the climate change agreements. Science, development and diplomacy. In: Harris, P. G. (Ed.): Confronting environmental change in East and Southeast Asia: Eco-politics, foreign policy and sustainable development. London, 135-150.

LI, Y./NisHIOKA, S. (1999): Global warming impacts on China. Beijing. (Energy Research Institute).

NoRDQVIST, J. (2005): China and climate co-operation. Prospects for the future. Stockholm. (Naturvårdsverket, Rapport 5448).

OECD (Organisation for Economic Co-operation and Development)(2005): China in the global economy. Governance in China. Paris.

OECD (Organisation for Economic Co-operation and Development)(2007): OECD environmental performance reviews China. Paris.

Panayotou, T. (2003): Economic growth and the environment. Geneva. (Spring Seminar of the UN Economic Commission for Europe, March 3, 2003).

People's Daily Online (2002): Floods, droughts continue to harass China. In: People's Daily Online 27.8.2002; Internet: http://english.people.com.cn/ 200208/27/eng20020827_102162.shtml, 10.12. 2007.

Perman, R.J./ Stern, D. (2003): Evidence from panel unit root and cointegration tests that the environmental Kuznets curve does not exist. In: Australian Journal of Agriculture and Resource Economics, (47)4, 325-347.

Planet Ark (2006): No weather relief for drought and flood-hit China. In: Planet Ark 15.5.2006; Internet: http://www.planetark.org/avantgo/dailynewsstory.cfm? newsid=36344, 13.12. 2007.

Ravallion, M./ CHEN, S. (2004): China's (uneven) progress against poverty. Washington, D.C. (World Bank Policy Research Working Paper 3408).

SCHIPPER, L. /NG, W.-S. (2004): Rapid motorization in China: Environmental and social challenges, Washington, D.C. (World Resources Institute).
Schwartz, J. (2004): Environmental NGOs in China: Roles and limitations. In: Pacific Affairs, (77)1, 28-49.

SEI (Stockholm Environment Institute)/UNDP (United Nations Development Programme)(2002): China human development report 2002. Making green development a choice. Hong Kong. (Internet: http://www. undp.org.cn/downloads/nhdr/nhdr2002.pdf, 7.6. 2005.

SHEN, Y. (2004): An overview of glaciers. Retreating glaciers and their impact in the Tibetan plateau, Lanzhou. (WWF, Internet: http://www.wwfchina.org/ english/downloads/chinaglaciers.pdf, 12.12. 2007.

SIARNACKI, A. (2006): The evolving role of environmental NGOs in China. Internet: http://www.ngowatch. org/articles.php?id=311, 9. 8. 2006.

State Council of the People's Republic of China (2006): Environmental protection in China (1996-2005). Internet: http://news.xinhuanet.com/english/2006-06/05/ content_4647221.htm, 6.8.2006.

TAubmann, W. (2007): Naturräumliche Gliederung und wirtschaftsgeographische Grundlagen. In: Fischer, D/ Lackner, M. (Hrsg.): Länderbericht China. Bonn, 1549. (Bundeszentrale für politische Bildung).

UNDP (United Nations Development Programme) (2005): China human development report 2005. Development with equity. (Internet: http://www.undp.org.cn/ downloads/nhdr2005/NHDR2005_complete.pdf, 30.7.2005)

UNEP (United Nations Environment Programme) (2004): GEO year book 2004/5. An overview of our changing environment. Nairobi. (Internet: http://www. unep.org/geo/yearbook/yb2004/index.htm, 30.8. 2005).

World Bank (1997): Clear water, blue skies. China's environment in the new century. Washington, D.C. (China 2020 Series).

World Bank (2006): Clean energy and development: towards an investment framework. Washington, D.C. (Internet: http://siteresources.worldbank.org/DEVCOMMINT/Documentation/20890696/DC2006-0002(E)CleanEnergy.pdf, 25.8. 2005).

World Bank/SEPA (The State Environmental Protection Administration)(2007): Cost of pollution in China. Economic estimates of physical damages. Washington, D.C. Worldwatch Institute (2006): State of the world 2006. Special focus: China and India. London. (Earthscan). Xinhua (2004): Floods, droughts cost China 200 billion yuan in 2003. (Internet: http://english.people.com.cn/ 200402/11/eng20040211_134479.shtml, 9.8.2006).

YE, Z. (2003): China's emerging civil society.Beijing.

ZHENG, Y./CHEN, M. 2006): China promotes geen GDP for more balanced development.Nottingham. (China Policy Institute). 